\title{
Tomasz KwoKa
}

\section{Dom i kuća w języku i tradycji Serbów i Czarnogórców}

Słowa klucze: dom, rodzina, zadruga, etymologia, historia języka

Artykuł przedstawia historię dwóch wyrazów języka serbskiego o tym samym lub podobnym znaczeniu, które swoim początkiem sięgają epoki prasłowiańskiej i praindoeuropejskiej, a związane są w sensie zarówno społecznym i rodowym, jak również ekonomicznym z życiem człowieka od samego początku. Mowa o wyrazach dom i kuća, które cechuje specyficzny paralelizm rozwoju semantycznego i specjalizacja w językach słowiańskich, z których pierwszy to ogólnosłowiański termin mający swe dokładne odpowiedniki w licznych językach indoeuropejskich, a drugi, będący prasłowiańskim nowotworem, obecnie występuje na południu i wschodzie Słowiańszczyzny.

W celu ukazania kształtowania się rozwoju tych wyrazów w okresie wspólnoty prasłowiańskiej oraz $\mathrm{w}$ toku rozwoju zakresu semantycznego w okresie historycznym języka serbskiego, pragnę przedstawić kilka faktów etymologicznych, ilustrujących pochodzenie i rozwój wyrazów, które zaczerpnąłem ze słowników etymologicznych oraz słowników języka prasłowiańskiego - krakowskiego Słownika prasłowiańskiego (SP) i moskiewskiego słownika Этимологический словарь славянских языков (ESSJa). Posiłkować się będę również artykułem prof. Aleksandra Lomy (2004: 15-42), w którym ten belgradzki indoeuropeista zajmuje się analizą grupy wyrazów słowiań- 
skich z zakresu stosunków społecznych na tle indoeuropejskim, za punkt wyjścia biorąc przetłumaczony przez siebie słownik instytucji indoeuropejskich Emile'a Benveniste'a - Le vocabulaire des institutions indo-européennes (Бенвенист 2002).

Praindoeuropejski i ogólnosłowiański wyraz *domъ w SP zdefiniowany został jako 'pomieszczenie gdzie człowiek żyje ze swoją rodziną, domus, domicilium', 'wszystko co jest w domu, rodzina, mienie, majątek', 'ród, pokolenie', 'strony rodzinne, kraj ojczysty'. Wyraz kontynuuje ie. temat na -u*domu-, odpowiednik łac. domus domūs f. 'dom’ oraz tematy na -o-: gr. $\delta o ́ \mu o \varsigma$

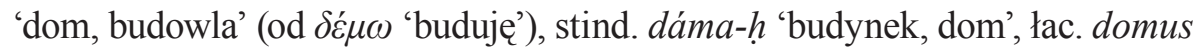
domi 'dom' (tu także należy litewski nãmas, zwykle pl. namaĩ 'dom' i łot. nams 'ts.'; por. SP IV: 98-100). Boryś wywodzi z pie. *domu-s (/ *domo-s) derywowanego od pierwotnego pie. wyrazu, rekonstruowanego m.in. w postaci *dōm- , por. stind. dám 'dom', orm. tun 'dom', należącego do pie. pierwiastka *dem- 'dom, rodzina' (Boryś SEJP: 118). A więc pierwotnie to nazwa 'domowników, mieszkańców jednego domu', z której rozwinęło się późniejsze 'dom, budynek mieszkalny'. Inaczej podaje Skok, według którego byłaby to forma powstała od *dem(o)- 'budować, tworzyć', oznaczająca pierwotnie 'to, co zbudowane', wtórnie zaś 'dom' (Skok ER I: 424-425).

Emile Benveniste oddzielał ie. *dem- 'dom; rodzina' (łac. domus, psł. *domъ) od *dem(z) 'budować'. Pod wpływem jego prac rozpowszechniła się opinia o braku związku między ie. *domos / *domus i *demō 'budować', na tej podstawie, iż ie. *domos / *domus pierwotnie oznaczało przede wszystkim nie budynek, budowlę złożoną ze ścian i dachu, lecz ogólną organizację rodową, rodzinę (ESSJa V: 72-73). Z tym poglądem Benveniste'a polemizuje Loma (2004: 19), uznając za dyskusyjne rozdzielanie przez francuskiego badacza terminu $z$ dziedziny kultury materialnej od terminu instytucji społecznych. Jak zauważa Loma, użycia wyrazu dom w jęz. słowiańskich, a poniżej widać to będzie wyraźnie na materiale serbskim, wskazywać mogą na równoległe i stare używanie wyrazu dom zarówno w znaczeniu 'budynek', jak i społecznym 'rodzina, strony rodzinne'. Taka dychotomia znaczeń spotykana jest także w przypadku wyrazu kuća 'budynek' i 'rodzina, zadruga', choć jego pierwotne znaczenie na pewno było konkretne, wywodzące się od budowy domu.

Przechodząc do materiału serbskiego, wyraz dôm, według współczesnych słowników serbskich, definiowany jest przede wszystkim jako 'budynek 
mieszkalny, miejsce zamieszkania', 'dom rodzinny, ognisko domowe'1 oraz w znaczeniach społeczno-rodowych: 'rodzina, wspólnota rodzinna, domownicy', 'ród, plemię; rodzina; dynastia; pochodzenie', 'szlachetna, szanowana rodzina', dial. 'dom, rodzina, z którą mieszka dziewczyna przed ślubem', dial. 'dom, rodzina męża, do której wchodzi mężatka po ślubie' (RSAN).

$\mathrm{W}$ średniowiecznych zabytkach serbskich znaczenie wyrazu dom pokrywa się ze współczesnym i oznacza 'miejsce zamieszkania rodziny' oraz powszechniej, w znaczeniu socjologicznym, 'rodzina, wspólnota rodowa zamieszkująca jeden dom'. Termin oznaczał także bliską rodzinę, dom zadrużny oraz dom władcy. Z tych znaczeń rozwinęły się kolejne - 'wszystko, co znajduje się w domu i czym zarządza głowa rodziny, domownicy, majątek' (MS: 75 z 1302-1321 r.), 'ród, plemię, pokolenia' (MS: 9 z 1222-1228 r.) oraz 'dom, krewni, szersza rodzina, bractwo, klan' (RJAZ). W tych samych znaczeniach poświadczony także w serbskich słownikach, np. u Vuka Karadžicia (SR): dôm 'das Haus, domus (familia)', 'vornehme Familie, familia nobilis'. W XIX wieku w Czarnogórze podczas tworzenia kodeksu prawnego (OIZ CG) postanowiono, że terminy dom i kuća będą równoznaczne.

W słownictwie ludowym, a także pracach etnograficznych wyraz ten to najczęściej nazwa bliskiej rodziny (= kuća, familija, porodica). W gwarach poświadczony w znaczeniach 'dom' i 'rodzina': dôm (RZag, Njegoš, RProš, RVG, RKM), dóm (RTimok, RLesk) oraz dôm, döm 'dom', 'budynek, w którym znajduje się urząd publiczny' (RSGV). W plemieniu Kučów to 'osobna rodzina na oddzielnym domostwie, kuća' (KBP: 29).

W znaczeniu budynku mieszkalnego, poświadczony w średniowiecznym słowiańskim przekładzie greckiego kodeksu Zemljoradnički Zakon z poł. XIV wieku. W słowniku rusko-słowiańskim Kurzbeka z końca XVIII wieku w znaczeniu 'dvorb, das Haus' (Kurzbek). W monografii Rakicia poświęconej terminologii rodowej, dom to 'dom, kuća' (Ракић 1991: 63).

Od wąskiego znaczenia 'miejsce, gdzie mieszka człowiek z najbliższymi', poprzez 'dom i zabudowania, gospodarstwo', znaczenie wyrazu rozszerza się i obejmuje także 'wieś, miasto, państwo, w którym się ktoś urodził', 'ojczy-

1 Dial. 'strony rodzinne, ojczyzna', 'dom, budynek w ogóle', 'pomieszczenie mieszkalne domu, w którym mieszka głowa rodziny z rodziną, pokój’, reg. 'dom z zabudowaniami wokół, zagroda, domostwo, majątek’ oraz ‘jedna z instytucji, które tworzą parlament, izba parlamentu'. 
zna, strony rodzinne', a więc geograficzne miejsce, z którego ktoś pochodzi, gdzie się urodził i które uważa za swoją ojczyznę.

Od średniowiecza wyraz często poświadczony w znaczeniach metaforycznych, jako 'dom boży, cerkiew, świątynia' (od XIV w., np. DH), 'klasztor, monaster', 'relikwiarz', oraz 'ziemia; grób; dusza'. W słowniku Mihajlovicia (poświadczenie z 1794 r.) Domъ 'parlament' (PosrbOV). Zbliżone znaczenie administracyjne 'Rathhause' także w słowniku Kurzbeka.

Wyraz ten od XV w. poświadczony w Czarnogórze, w znaczeniu z zakresu terminologii rodowej i obrzędowej, dotyczy nazewnictwa domów panny młodej. Niezamężna dziewczyna, zanim wyjdzie za mąż, swoją rodzinę nazywa dom. Po zawarciu małżeństwa sytuacja ulega zmianie - ‘ženi je dom muževa kuća, a rod očeva'2

Wyrazem podobnym w swym charakterze i rozwoju jest stara pożyczka germańska hiža, psł. *chys'a i *chyz'a (i starsze *chysz i *chyzb) 'dom', która rozwinęła się prawdopodobnie z formy *hūsa. Serbskie hiža, hïža, iža i iža w RSAN w znaczeniu 'dom, budynek', 'osobne pomieszczenie w domu, w którym się gotuje, kuchnia; pokój w ogóle' i 'rodzaj chleba przygotowywanego na Boże Narodzenie'. Wyraz ten, choć w Serbii ${ }^{3}$ rzadko, poświadczony jest od najstarszych zabytków (od XIII w., RiKSS) w obydwu znaczeniach, jako 'dom' oraz 'rodzina i plemię'. W XIX wieku w SR formę hï̌̌ina, ǐžina definiuje jako 'buda, komórka, w której mieszka małżeństwo - część zadrugi; komórka, w której przechowuje się jedzenie'. W Serbii średniowiecznej termin wypierany był przez wyrazy kuća, dom i zachował się jedynie na obrzeżach serbszczyzny - w Timoku i Pirocie. W gwarze Pirotu to hiža 'dom, pomieszczenie w chacie wiejskiej, w której znajduje się palenisko, kuchnia' (RPirot), natomiast w Timoku - iža 'dom, kuća', 'pomieszczenie w domu, w którym znajduje się ognisko, kuchnia’ (RTimok).

Dużo bardziej skomplikowany rozwój charakteryzuje nowotwór słowiański, psł. *ketja, który obecnie zachował się na południu i wschodzie Słowiań-

2 A. Jovićević w monografii o Nahii Riječkiej pisze, iż dom to „мјесто у кући, гдје се пребива, гдје се налази домаћин и домаћица. [...] Мјесто, гдје пребива, жена назива домом кућу у којој је удата, гдје домује (вијек проводи) за разлику од рода, гдје је рођена и одакле је удата" (Riječka: 145).

3 Wyraz częściej występuje na terenach chorwackich, poświadczony szerzej w słownikach chorwackich w formach his, hisa, hiš, hiša 'kuća', 'zadruga', 'porodica, pleme' i 'soba' (RJAZ). 
szczyzny ${ }^{4}$. Według ESSJa *kotja w pierwotnym swym znaczeniu nawiązywała do psł. *kotı 'kąt wewnętrzny's. Za taką etymologią przemawiaja dane archeologiczne opisujące najstarsze formy słowiańskiego budownictwa mieszkalnego, lokujące ognisko w rogu izby prymitywnego starosłowiańskiego domu. Psł. *ketja byłby więc według słownika derywatem z suf. -ja od rzeczownika *kotz (w ESSJa odrzucono możliwość derywacji od czasownika *kqtati/*kutati), który oznaczałby pomieszczenie, izbę z paleniskiem lub piecem w rogu - była to prasłowiańska innowacja nie tylko językowa, ale także kulturowa. Na taką etymologię wskazywać też może znaczenie rosyjskie podane w ESSJa: 'место у очага; часть дома где раскладывался очаг; задняя часть или угол в русской печи; кухня; пространство между стеной и русской печью', jako analogia wschodnio- i południowosłowiańska. Znaczenie pomieszczenia z piecem, kuchni, w toku rozwoju sposobu budowy domów pojawi się także w Serbii.

Wiadomo, że ognisko umiejscowione w rogu izby charakteryzowało przede wszystkim ziemianki lub półziemianki, które były najstarszym typem budynków mieszkalnych dawnych Słowian. Były to domy mniej lub bardziej zagłębione w ziemię, o tradycji sięgającej jeszcze epoki kamiennej. Używano ich głównie na terenach lessowych, gdzie o drewno było trudno, a spoistość gruntu umożliwiała pionowe wkopywanie się w ziemię bez obawy zawalenia się ścian (SSS: 184) ${ }^{6}$. W okresie późnoantycznym i wczesnośredniowiecznym ten typ budownictwa dotyczył przede wszystkim siedlisk Sklawinów i Antów, ale już nie północno-zachodnich Wenetów. Młodszy typ domu południowosłowiańskiego, w swej najstarszej formie, scharakteryzować możemy już jako ,jednoizbowy drewniany budynek, którego rzut przyziemia jest niemal kwadratowy. Ognisko otwarte znajduje się na środku izby” (SSS: 187).

4 Wyraz poświadczony jest m.in. na południu w bułg. къ́щ̧a 'дом, комната; семейство’, тас. куќa ‘дом’, słe. kóča 'крестьянская, хижина, лачуга’ oraz na północy w strus. куча 'хижина, шалаш, жилая постройка', ку́ча 'шалаш из столбов в рост человека, сверху обложенный дерном, землей’, кутя́ ‘часть избы перед русской печью’, кутья́ 'место в избе у входной двери', 'кухня', ку́ча 'клеть для птиц; хлев для свиней', brus. dial. ку́чка 'хлев; небольпая хатка', ‘место под печью’ (ESSJa XII: 70-74).

5 W przeciwieństwie do wyrazu * $Q g$ bl oznaczającego 'kąt zewnętrzny', 'kąt, róg, narożnik', wyraz *kotъ miał znaczenie 'wewnętrzna strona zetknięcia się dwu ścian, kąt wewnętrzny’ (por. Boryś SEJP: 227).

${ }^{6}$ Jak podaje SSS (s. 184-188), domy z ogniskiem w rogu odkryto m.in. pod Praga (obok odkrytych także ziemianek z X w. z paleniskiem na środku izby). 
Wyraz *ketja jako wyraz prasłowiański, ale nie ogólnosłowiański, charakterystyczny jest dla języków południowo- i wschodniosłowiańskich (obecny w języku polskim wyraz kucza jest zapewne pożyczką z ukraińskiego ${ }^{7}$ ). Według Lomy, nie należy jednak bezdyskusyjnie przyjmować etymologii ESSJa, jakoby *ketja był derywatem od rzeczownika *kQtъ 'kąt wewnętrzny', a nie od czasownika *kqtati / *kutati (*kqtiti / *kutiti), por. 'гнуть(ся); прятать; копаться; искать; кружить, крутить; грести; охранять, воспитивать; затевать; действовать' (ESSJa), za tym drugim przemawia bowiem argument słowotwórczy. Przykładami derywacji odczasownikowej z suf. *-ja, obok prawdopodobnej *kotja 'szałas, chata, dom' derywowanej od *kqtati 'pokrywać, okrywać', są między innymi derywaty typu *gord'a 'grodzenie; ogrodzenie, grobla, miejsce ogrodzone' od *gorditi 'grodzić, budować', *paša 'pasienie, pasza, pastwisko' od *pasti ‘paść' itp. Te i inne przykłady tworzenia przede wszystkim nazw czynności, które najczęściej ulegały konkretyzacji w nomina acti, instrumenti, ale czasem także w nomina loci, podaje w $\mathrm{Za}$ rysie słowotwórstwa prasłowiańskiego Franciszek Sławski (SP I: 81-83). Podobną etymologię podawał Petar Skok, według którego pierwotne południowosłowiańskie znaczenie brzmiałoby 'schronienie, kryjówka, ukrycie, (lub) miejsce, w którym się dba o kogoś', 'schronienie z ogniskiem, wokół którego gromadziła się rodzina, zadruga' (od *kotati 'dbać, troszczyć się, wychowywać, ukrywać) (Skok ER, t. II: 221-222). W tym kontekście ciekawy jest przykład polskiego wyrazu zanotowanego w XII w. po łacinie przez niemieckiego kronikarza contina = kotina, kqcina 'świątynia pogańska u dawnych Słowian’ oraz przenośnie ‘schronienie, przytułek, dom’ (Sławski SEJP I: 318) i płd.-słow. kutina 'stroma morska zatoka', 'nisko położone podłoże przy rzece lub potoku' w Banacie, a więc płd.-słow. *kqtina to 'morski lub rzeczny przesmyk, cieśnina, wąwóz’. W tym przypadku, jak zauważa Loma (2004: 19-23), można by szukać analogii z serbskim wyrazem krov 'dach', ros. крымиа 'ts.' od czasownika *kryti. Jako argument przemawiający za etymologią ESSJa, Loma (2004: 19-23) przytacza psł. frazę *babbjo kQtъ 'część domu koło ogniska, gdzie siedzą stare kobiety'.

7 Według Sławskiego (Sławski SEJP I: 310-311), wyraz ten w jęz. polskim oznaczający 'szałas, prymitywna buda z chrustu, chatka', a także regionalnie 'licha chatka, szałas, szopa np. na drzewo; zagroda dla kur, prosiąt, cieląt; wgłębienie pod trzonem ogniska', należałoby wywodzić z psł. *kuk-ja 'kupa', jako nawiązanie do prymitywnej chatki przypominającej kopiec, kopę, kupę. 
Obydwie etymologie jako możliwe podają słoweńscy badacze, Marko Snoj (Snoj SES: 287) i France Bezlaj (Bezlaj ESSJ II: 52). Byłby to wyraz spokrewniony z psł. *sb-kqtati (*kqtati i *kutiti) 'ukrywać, chronić, troszczyć się, zawijać', pol. lud. kutać 'owijać, pokrywać'. Wyraz miałby znaczenie pierwotne 'to co ukryte; to co pokryte' (por. serb. krov 'dach') lub byłby derywatem z sufiksem -ja utworzonym od psł. *kotb 'kąt; kąt wewnętrzny' w znaczeniu 'to, co ma katty; kwadratowy, a nie okrągły, budynek' lub, w związku z organizacją domu prasłowiańskiego, 'budynek, w którym ognisko znajdowało się w kącie'.

Jakiejkolwiek by etymologii nie przyjąć, *kotja niewątpliwie jest psł. nowotworem powstałym ,bilo da se označi određen, noviji tip zgrade, bilo da se leksički diferenciraju značenja 'kuća kao zgrada' i 'kuća kao porodica, zadruga', tako da bi se ovo drugo ostavilo baštinjenoj reči *domb” (Loma 2004: 21). Podsumowując swój wywód na temat pochodzenia wyrazu, Loma stwierdza, $\mathrm{iż}, \mathrm{u}$ jednom trenutku poslužila našim dalekim precima da 'rematerijalizuju' već uveliko 'sociologizovano' značenje starijeg, iz praindoevropske epohe nasleđenog termina *doms” (2004: 23), choć później także wyraz kuća uległ uspołecznieniu, pojawiając się między innymi w konstrukcjach: oženiti se iz dobre kuće, samohrana kuća, kraljevska kuća.

We współczesnym języku serbskim, küća to przede wszystkim 'dom, budynek, chata', 'dom rodzinny, ognisko domowe; rodzina's oraz 'rodzina; wszyscy, którzy wspólnie mieszkają w domostwie, domownicy, najbliższa rodzina', 'domostwo, gospodarstwo domowe', 'ród, pokolenie; rodzina panująca, dynastia', dial. 'większa wspólnota rodzinna (najczęściej bracia wraz ze swoimi rodzinami), której członkowie mieszkają we wspólnym domostwie', 'wspólnota wielu rodzin noszących to samo nazwisko, powiązanych pochodzeniem, bractwo, plemię ${ }^{9}$ RSAN.

Na przestrzeni wieków, podstawowymi znaczeniami wyrazu kuća było „место за становање, зграда, кућа као мање насеље, кућа као најмања економска и управна јединица у селу” oraz, znaczenie wtórne, synoni-

8 Dial. 'kompleks budynków należących do jednego domostwa, zagroda, obejście', 'sprzęty domowe, wyposażenie domu', dial. 'część wiejskiej chaty przeznaczona do mieszkania, w której znajduje się palenisko, gdzie się gotuje, je i spędza największą ilość czasu’, 'kuchnia', 'pokój', 'pomieszczenia w domu, przeznaczone dla zwierząt domowych'.

9 Także 'instytucja kulturalno-oświatowa, państwowa itp.; sąd; gmina; budynek, w którym się znajduje taka instytucja', 'przedsiębiorstwo', 'miejsce, w którym się mieszka, żyje; strony rodzinne, ojczyzna', 'majątek rodziny, sprzęty domowe, domostwo'. 
miczne do wyrazu dom: „кућа родбинска заједница - инокосна породица у ужем смислу, задружна породица у ширем и мало братство у најширем значењу” і „као родбинско-економска заједница, кућа као најмања управна економска и пореска јединица, са читавим низом колективних одговорности, права и дужности у држави и селу, владалачки дом, манастирска заједница" (Чубриловић 1959: 12, 16). W rozwoju semantycznym wyrazu (obok paralelnego rozwoju $\mathrm{z}$ domem) istotne jest mieszanie funkcji topograficznych, mieszkaniowych i własnościowo-prawnych z rodowymi i społecznymi (socjalnymi). W swej monografii Čubrilović (Чубриловић 1959: 45) proponuje, aby wyrazu kuća używać na określenie jedynie domu jako budynku, miejsca zamieszkania oraz jednostki administracyjnej (a więc w znaczeniu pierwotnym), natomiast terminy rodzinne zastępować bardziej odpowiednimi wyrazami typu porodica, obitelj, dom.

W dokumentach pisanych jęz. staroserbskiego kuća to 'saedes, domus, budynek, w którym ktoś mieszka, siedzi, przebywa, dom, ognjište, dim' (RiKSS, $\mathrm{KD}, \mathrm{DH})$. Wyraz poświadczony także m.in. w SR küća 'das Haus, domus', 'der Hof, aula, palatium, dwór', 'die Küche, culina' oraz 'vornehme Familie, familia nobilis'.

Według M. Milićevicia kuća oznaczał 'dom, w którym pali się wspólny ogień, a stąd rozwinęło się i znaczenie 'część domu, pomieszczenie, w którym znajduje się palenisko, które znajduje się najczęściej zaraz za wejściem, przed soba; kuchnia, kujna' (por. Милићевић 1984: 11). Terminem kuća określano 'chaty wiejskie' oraz 'domy miejskie'. W Czarnogórze, w plemieniu Paštroviciów, znaczenie 'miejsce zamieszkania rodziny, budynek, dom' jest znaczeniem podstawowym, natomiast znaczenie 'rodzina, krewni' wtórnym. W gwarach w tym znaczeniu formy: küća (Njegoš, UR, RRad), kuća (RKam), kúća 'budynek, w którym się mieszka', 'bożonarodzeniowy chleb obrzędowy' (RTimok), küća 'dom, kuća' (w tym znaczeniu także küča; varoška, opštinska kuća 'budynek urzędu lokalnego', gospodnja kuća 'cerkiew, kościół' i w znaczeniu przenośnym večna kuća 'grób'), 'kuchnia', 'rodzina', 'szałas', 'w zabawie dziecięcej: krąg w ziemi, w który rzuca się kawałek drewna', 'nagrobek' (RSGV).

W przypadku wspomnianej wcześniej techniki budowlanej, przedstawiała ona najstarszą formę budownictwa domów - ziemianki i półziemianki. System ten uległ zmianie w średniowieczu. Na terenie Serbii, aż do wyzwolenia spod władzy tureckiej, domy budowano z drewna (wynikało to przede 
wszystkim z dostępności tego budulca na lesistych terenach Bałkanów). Były to niewielkie, bardzo proste, lekkie i biedne budynki jednoizbowe, w zależności od regionu, najczęściej budowane z drewnianych bali lub bierwion poziomych w konstrukcji zrębowej, na wybrzeżu także z kamienia. W izbie, na środku paliło się ognisko, wokół którego skupiało się życie rodzinne (Новаковић 2002: 93). W okresie panowania tureckiego, przede wszystkim w miastach, pojawił się nowy typ domów typu bałkańskiego (orientalnego) - domy dwupoziomowe (na parterze kuchnia i dwa pokoje, a na piętrze wokół divanhanu kilka pomieszczeń mieszkalnych) przeznaczone dla bardziej licznych rodzin.

W okresie późniejszym prymitywny wiejski typ budowy został wyparty przez domy kryte gontem i budowane z plecionki oblepionej gliną lub cegieł suszonych na słońcu. Potem, od lat 30. XIX w. rewolucję w budownictwie wywołało wprowadzenie nowych technik budowlanych, m.in. cegły i szkła. Domy wzbogaciły się o kolejne pomieszczenia (a wyraz kuća o kolejne znaczenia): obok kući, głównego pomieszczenia, gdzie toczyło się życie rodzinne i znajdowało się ognjište, pojawiła się także soba, służąca domownikom jako sypialnia. Kiedy budynek stał się dwu- i wieloizbowy, wówczas pojęcie kuća otrzymało nowe znaczenie, ograniczane tylko do tego pomieszczenia, które usytuowane było zaraz za wejściem, i w którym było palenisko (pomieszczenie to określano następnie mianem kujna, kuhinja 'kuchnia') (Милићевић 1984: 11). W takim znaczeniu wyraz notuje słownik Vuka (SR) kuća 'die Küche, culina' oraz 'Mutterkuchen'. To główne pomieszczenie, z nieustannie palącym się ogniem, wokół którego zbierali się domownicy, gdzie przyrządzano i spożywano posiłki, debatowano. Panowały w nim niepisane zasady, wedle których gospodarz zajmował główne miejsce, mając po swej prawej stronie starszych, a po lewej młodszych członków rodziny.

Od średniowiecza kuća to także nazwa jednostki administracyjnej i ekonomicznej na wsi (KD, art. 179). W średniowiecznej Serbii jednostką statystyczną były domy, kuće, tj. wspólnoty rodzinne zamieszkałe w jednym domu, które odpowiadały za wszystkich swoich domowników. To od domów pobierano średniowieczne podatki, na domy były rozdzielane robocizny. Domostwo było również najniższą jednostką objętą systemem odpowiedzialności karnej i zabezpieczenia wykroczeń popełnianych przez domowników 
(Чубриловић 1959: 12) ${ }^{10}$. W późniejszym czasie znaczenie nie uległo istotnym zmianom. Za panowania tureckiego, w sułtańskich defterach oraz zapiskach tureckich i weneckich, kuće to najmniejsza jednostka we wsi (stąd w Czarnogórze podatek: kućarina) obok mahali, a także synonim ognjišta, dima. Taki podział pojawił się w pierwszym spisie Czarnogóry za panowania Skender-bega Crnojevicia z 1521 i 1523 r. W formie pluralnej zaś kuće, wyraz otrzymuje znaczenie geograficzne i oznacza 'osiedle, osadę' (Чубриловић 1959: 13).

W średniowieczu kuća, podobnie jak i dom, oznaczała także 'monaster, klasztor, wspólnotę zakonną mieszkającą w monasterze'. Potem także jako 'sklep, punkt handlowy' ('taberna mercatoria' od poł. XIII w., por. RiKSS). W średniowieczu także jako 'dom władcy, dom rodziny panującej, dwór'. W słowniku Daničicia (RIKSS) od XIV w. jako 'patria' (por. MS: 168).

Rozwój znaczenia kuća postępował dalej, ku znaczeniu 'dom z ziemią, majątkiem, dwór' (pośw. od XIV w., np. KD). Rovinski pisał, że wyrazem kuća nie nazywano wyłącznie domowników, ale także wszystko co do domu należało: majątek, zwierzęta (Ровински 1998, I: 146). W powiedzeniu: E, čovje od kuće!, wyraz występuje w znaczeniu określenia moralnego, 'dobry dom, dobre pochodzenie, szlachetne pochodzenie'. Stąd też kućić to człowiek pochodzący ze starego, znacznego rodu, znany z zasług jego członków (Ровински 1998, I: 147).

W znaczeniu wtórnym, socjologicznym, wyraz poświadczony od początków piśmiennictwa, m.in. w słowniku Daničicia (RiKSS) w znaczeniu 'familia'. Jako wyraz określający wspólnotę rodzinną, zarówno zadrużna (wielopokoleniową), jak i inokosnq (jedno- lub dwupokoleniową), synonim porodica, familija, zadruga, poświadczony od średniowiecza, np. w Kodeksie Dušana. „Стари изрази обитељ и породица, фамилија, и новија реч задруга никад нису тако примењивани за означавање породице, као кућа било у ужем појму инокосна или у ширем задружна кућа. Под овим називом обухваћен је појам и шире родбинске заједнице братства у Црној Гори” -

10 „Кућа као појам за зграду и чељад што у њој живе, уствари је и у Средњем веку најнижа економска и управна јединица, са читавим низом колективних права и дужности - како њених чланова међусобно тако према држави, властелину, селу: заједничко плаћање њених чланова државних пореза и феудалне ренте, колективна кривична одговорност - према државној и феудалној власти за дела, почињена од њених чланова, крвна освета по обичајном праву итд” (Чубриловић 1959: 11-12). 
poświadczone w Lice, Slawonii, Dalmacji, Hercegowinie, Czarnogórze i Boce Kotorskiej (Чубриловић 1959: 14-15). W monografii Rakicia to 'rodzina, węższa lub szersza, obejmująca także pojęcie domostwa - wspólnoty rodzinno-majątkowej’ (Ракић 1991: 68). Aż do wydania słownika Vuka w 1818 r. określał także zadrugę, szeroką wspólnotę rodzinną, w której obowiązywała wspólnota dóbr, pracy, produkcji, jedno palenisko i jeden naczelnik.

Valtazar Bogišić wprowadził do OIZ CG termin kuća jako wyraz ogólny, którym lud nazywał prostą (inokosna kuća) lub złożoną rodzinę (zadružna kuća). Opierał się przy tym na świadectwie znanych czarnogórskich twórców ludowych, m.in. na Stefanie M. Ljubišy i Vuku Vrčeviciu. Wyjaśnił w ten sposób powód, dla którego zdecydował się do OIZ CG wprowadzić ten termin, jako synonim wyrażeń kućna zajednica i domaća zajednica.

Jak pisał A. Ilić, kuća to „породична институција, састављена од домаће чељади, међу којима се манифестује: заједница имања, живљења, радње и тецива" (Илић 1936: 24). Кис́a jako wspólnota domowników obejmuje nie tylko męskich i żeńskich członków rodziny, ale także każdą osobę doma rođena i zakonito primljena u kuću, tzn. każdą osobę urodzoną we wspólnocie lub adoptowaną, a także żony członków rodziny. Wspólnota majątku kući oznacza, iż wszelkie dobra należące do rodziny / domu są wspólne i dysponować nimi można jedynie za zgodą wszystkich członków rodziny (każdy z domowników może posiadać także swój prywatny majątek). Wreszcie, kuća to wspólnota etyczno-moralna (wychowanie członków rodziny, opieka nad nieletnimi itp.) i organizacja ekonomiczno-gospodarcza.

Kuća pojawia się także w szerszym znaczeniu, jako 'bractwo, małe bractwo', 'wspólnota rodzinna, w której zamieszkują bracia i kuzyni z żonami i dziećmi'. W swej pracy Rakić pisze, iż termin ten ma czasem znaczenie szersze, oznaczając ród, bractwo (=klan), synonimicznie do takich pojęć jak: verige, dom, dim, komoštre, ognjište, odžak (Ракић 1991: 68). W literaturze naukowej dotyczącej terminologii życia plemiennego, kuća obejmuje znaczenie 'małe bractwo', 'bractwo lub część bractwa'. Między innymi Filipović (Филиповић 1945: 97) dzieli bractwa na mniejsze jednostki: kuće, rod, blizikę. Kuća to także nazwa grupy rodzin z jakiegoś znanego, wyjątkowego, naczelnego bractwa.

W tym miejscu więcej uwagi należałoby poświęcić określeniom rodziny, wspólnoty rodowej. Wyrazami kuća i dom aż do XIX w. określano zarówno niewielkie rodziny jedno- lub dwupokoleniowe (późniejsze określenia: ino- 
kosna kuća / porodica, inoko(v)ština 'mała wspólnota rodzinna, najczęściej składająca się z rodziców i ich dzieci, którzy mieszkają na wspólnym majątku i prowadzą wspólne gospodarstwo' RSAN), jak i wielkie, wielopokoleniowe wspólnoty typu zadrużnego. Według Vujačicia (Вујачић 1977: 31), inokosna kuća to 'najmniejsza wspólnota krwi, rodzina złożona z dwóch pokoleń (rodzice z dziećmi)'. W swej pracy na temat rodziny w Czarnogórze podaje również inne serbskie i czarnogórskie określenia takiego typu wspólnoty: inokoština, mala kuća, slaba kuća, nejaka kuća, samština, siromašna kuća, podczas gdy rodzina bez męskiego potomstwa jest określana jako: prazna, pustoš, pustinja, prazna pećina, pusta pećina, isprežna kuća, istražna kuća, istražbina, iskopana kuća, svratnica, svratna kuća (Вујачић 1977: 221). Obszerne informacje na temat struktury inokosnej rodziny w XIX w. podaje Bogišić (1999: 87), przywołując np. z Budvy, Hercegowiny i Katunskiej Nahii formę inokosna kuća.

Zanim nie został rozpowszechniony od połowy XIX w. przez Vuka Karadžicia (SR) wyraz zádruga'11 ('Hausgenossenschaft im Gegensatze der einzelnen Familie, plures familiae in eadem domo'), w tym samym znaczeniu, na określenie modelu rodziny wielopokoleniowej, w języku ludu oraz piśmiennictwie i aktach prawnych używano wyrazów kuća i dom. Przede wszystkim więc wymienione wyrazy pojawiały się same lub w konstrukcjach: kućevna zadruga, kućna zajednica, zadružna kuća, velika kuća, bogata kuća, golema kuća, dobra kuća, jaka kuća, snažna kuća, kućna družina, glavarska kuća, glasovita kuća ${ }^{12}$ (Илијић 1999: 15-16; Вујачић 1977: 216; Чубриловић 1959: 17). Poświadczenia gwarowe z Serbii to np. zadružna kuća (Ljubovija, Knjaževac) (Bogišić 1999: 84). Z terenu Czarnogóry w pracy Čubrilovi-

11 Współcześnie podawana definicja wyrazu zâdruga i zádruga to hist. 'wspólnota rodzinna, składająca się z większej liczby członków powiązanych między sobą bliskimi więzami pokrewieństwa (zwykle bracia z rodzinami), którzy mieszkają w jednym wspólnym domostwie i prowadzą wspólne gospodarstwo; wiejska wspólnota typu wielkorodzinnego', 'organizacja kolektywna, zrzeszenie powstałe w celu wykonania różnego rodzaju działań o charakterze gospodarczym', 'wspólnota, związek, zrzeszenie ludzi w ogóle' (RSAN).

12 Także zajednica, čeljad, famelja i familija, golema familija, porodica, velika porodica, obitelj, vit, hiža, društvo (Vojvodina), veliko ognjište, porodična zadruga, proširena porodica, zadružna porodica, skupština (porodična), braća, množina, glota, komun, bratstvo, braćija. W alb. Shtëpia e madhe 'velika kuća', łac. communio, niem. Hauskommunion, Kommunio, Hausgenossenschaft, Hausgemainschaft, Gemeinhauserei (w dokumentach i statutach Pogranicza Wojskowego z końca XVIII w. - 1737 i 1754 r.). 
cia (Чубриловић 1959: 15-17): kućna zajednica, bogata kuća, neodeljena kuća, zadružna kuća, domaća zajednica oraz zadruga, zadružna kuća (Bratonožići) (KBP: 516), zadružna kuća, velja kuća, dugačka kuća (Kuči) (KBP: 191), zadružni dom, zadružna kuća, velja kuća, musarifski odžak (Kuči: 104), zadružna kuća, zajednica, zadruga (Piperi) (KBP: 287), zadruga, društvo (Paštrovići: 239), zadružna kuća (Ровински 1998, t. II: 147), zadruga, porodična / kućevna zadruga (Rovca: 104). W Boce Kotorskiej terminowi zadruga odpowiada familija, odžak w Hercegowinie, a dom w Czarnogórze. W Hercegowinie i Nahii Katunskiej, na określenie szerszych rodzin używano form: zadružna kuća, zadružni su ljudi, dobra kuća, bogata kuća (Bogišić 1999: 87). W XIX-wiecznych aktach prawnych pojawiają się wymiennie: w OIZ z 1888 r.: kuća oraz zadruga i zadružna kuća, w GZS z 1844: zadruga, kuća, zadružna kuća. Termin zadruga od drugiej połowy XIX w. przyjęli badacze i naukowcy serbscy i chorwaccy.

Pierwsze pisane dane o instytucji serbskiej zadrugi pochodzą z dokumentów bizantyjskich oraz serbskich z XII i XIII w. ${ }^{13}$ Już w KD (art. 51, 52, 66, 70) wymienia się bezpośrednio kuća, ognjište, dim, zadružna kuća. W 77 nagłówkach dubrownickich statutów z XII i XIII w. pojawia się instytucja zadrugi. W tureckim fermanie z 1766 r. wśród Serbów wspomina się zadrugę jako formę wspólnego życia i pracy. Statut Varaždinskiego Pogranicza Wojskowego z 1737 r. wymienia Hauskommunion wraz z dokładnym opisem życia w niej. Pojawia się również w statutach Kotorskim i Grbaljskim (Илијић 1999: 17-19).

Terminami kuća, dom, w znaczeniu współcześnie znanym jako zadruga, oznaczano wielką, wielopokoleniową, tradycyjnie patriarchalną wspólnotę rodzinną, grupę krewnych wywodzących się od jednego ojca, szczególnie często występującą w społecznościach pasterskich (koczowniczych), złożoną z dwóch lub więcej rodzin nuklearnych. To instytucja społeczna, gospodarcza, rodowa, moralna i religijna, której głównymi cechami była wspólnota produkcji i konsumpcji, wspólnota majątkowa, władza reprezentowana przez naczelnika. Jako relikt ustroju rodowego, być może powstała w czasie wędrówek Słowian na Bałkany, a szerzyła się linearnie (kiedy tworzyło ją więcej

13 Należą tu dokumenty monasterskie, najpierw bizantyjskie, a potem także serbskie, które prowadziły ewidencję należących do nich dóbr, wspólnot, rodzin i ich majątków oraz dokumenty sądowe, prywatno-publiczne, akta sporządzane przy sprzedaży, kupnie, zamianie dóbr i majątków. 
pokoleń, np. dziadek, syn, wnuk) lub lateralnie (tworzona przez braci, którzy wraz ze swoimi rodzinami zostawali we wspólnym domu). Według Čubrilovicia (Чубриловић 1959: 17), był to kregostup życia gospodarczego $w$ dawnej Serbii.

Mirko Barjaktarović stwierdził, iż zadruga to „биолошко-сродничка, производно-економска и друштвена заједница, а код нас некако и традиционално-обичајна” (Барјактаровић 1981: 278). Tym samym część uczonych zakwestionowała prasłowiańskie pochodzenie zadrugi i jej przeważający wpływ na formowanie się wczesnego serbskiego modelu rodziny. W interesie średniowiecznego feudała leżało bowiem atomizowanie gospodarstw jemu podległych, aby tym samym uzyskać jak najwięcej podmiotów zobowiązanych do wykonywania robocizn lub płacenia danin. Przejawem tego są przepisy o sposobie podziału rodzin i przejmowaniu gospodarstw przez młode pary, zawarte $\mathrm{w}$ dokumentach średniowiecznych.

Rozwój zadrug przypada na czas panowania osmańskiego. W ogólnym chaosie administracyjnym okresu tureckiego na ziemiach serbskich, wśród kilku instytucji, które dbały i chroniły lud przez islamizacją, znajdowała się także zadruga, chroniąca rodzinę i naród, pomagająca wsi (najmniejszej terytorialnej i społecznej jednostce słowiańskiej) zachować jej serbski i chrześcijański charakter. W celu zapewnienia samowystarczalności ekonomicznej wspólnoty, w jej skład wchodzili przedstawiciele przeróżnych profesji: kowale, szewcy, kołodzieje, stolarze. Zadruga była miniaturą autonomicznej wsi średniowiecznej.

Była to instytucja demokratyczna, w której rządziła wspólnota, a nie jednoosobowo naczelnik. Starszeństwo domaćina było przywilejem i obowiązkiem, a władzę zwierzchnią posiadała rada dorosłych mężczyzn. „Старешина, у ствари, извршује одлуке већа, врши распоред послова и стара се, у име заједнице, да се све на време обави, да сви укућани буду снабдевани свим потребним, води надзор над понашањем укућана, заступа кућу на сеоском збору и код власти, и кад је гост у кући итд." (Филиповић 1945: 12). Dotyczy to zwłaszcza prawa dysponowania majątkiem zadrugi, który był dobrem wspólnym, należącym do wszystkich ${ }^{14}$.

14 Potwierdzały to także zapisy GZS „O zadružnom dobru bez saglasija sviju punoletnih i oženjenih muških glava jedan ili drugi nije vlastan raspolagati, kao ni prodati ili zadužiti” (§ 510). 
Znaczenia konkretne, nieabstrakcyjne, najczęściej z zakresu budowy lub wyposażenia domu mieszały się ze znaczeniami społeczno-rodowymi także w przypadku kilku innych wyrazów. Przykładem może być wyraz ògnjīste ${ }^{15}$ w znaczeniu 'rodzina', który powstał pod wpływem znaczenia obrzędowego. W mitologii słowiańskiej oraz serbskich wierzeniach, ognisko znajdujące się na środku izby (a dawniej w jej rogu) to centralne miejsce kultu rodzinnego, najważniejsze miejsce mikrokosmosu starego serbskiego domu, któremu podporządkowana była organizacja przestrzeni całego domu. Ognisko uważano za miejsce magiczne, miejsce przebywania mitycznych duchów przodków strzegących domu i domowników, opiekunów rodziny. To także miejsce, wokół którego toczyło się życie codzienne rodziny, gdzie przyrządzano i spożywano posiłki, wokół którego spano, gdzie podejmowano gości, zawierano z nimi porozumienia. Przy wtórze gęśli bajano o starych czasach, składano ofiary, korzystano z ciepła i światła z niego bijących ${ }^{16}$. Znaczenie 'rodzina, wspólnota rodzinna' nawiązuje więc do funkcji ognia, ogniska domowego zajmującego centrale miejsce i symbolizującego wspólnotę.

Do słowiańskiego ogniska, paleniska z ciagle na nim płonącym ogniem jako centrum domu, miejscem świętym, nawiązuje zapewne tureckiego pochodzenia wyraz òdža $k$ (i odžak), pierwotnie 'komin', 'palenisko w domu połączone z kominem, kominek', a wtórnie także 'dom, budynek domu' i 'ród, rodzina (najczęściej szanowana rodzina)’ (RMS).

${ }^{15}$ Znaczenia wyrazu: 'część chaty, gdzie znajduje się palenisko, gdzie się gotuje, spożywa posiłki i spędza najwięcej czasu', 'rodzaj pieca z kominem, kominek', 'część pieca, gdzie pali się ogień, palenisko', 'miejsce, gdzie pali się ogień; przestrzeń objęta ogniem'. W znaczeniu fig. 'dom rodzinny; majątek plemienia, rodziny', 'strony rodzinne, ojczyzna', 'wspólnota rodzinna, domostwo, gospodarstwo domowe', 'ośrodek bólu, centralne miejsce choroby', 'centrum, ośrodek ruchu, idei, zjawiska; ognisko' (RSAN).

${ }^{16} \mathrm{~W}$ związku z symboliką tego miejsca w domu istnieje szeroka literatura etnograficzna. Warto choćby wspomnieć opisy zamieszczone w haśle poświęconym ognisku w książce Š. Kulišicia, P. Ž. Petrovicia i N. Pantelicia, Srpski mitološki rečnik (Beograd 1998, s. 330-331), które określają jego znaczenie w kulcie domowym w Serbii: „Ono što je oltar u hramu, to je ognjište u kući. Gotovo svi domaći obredi, od rođenja do smrti obavljani su na ognjištu. Grešnici su se ispovedali na ognjištu. Stari ljudi umirali su na njemu". W okolicach miejscowości Pčinja „dete se prvi put okupa na domaćem ognjištu da bi se vezalo za kuću i da bi živelo”. Na terenie całej Serbii panna młoda „,pred polazak na venčanje, ljubi ognjište svojih roditelja, a posle venčanja ljubi ognjište mladoženjinih roditelja i tri puta ga obilazi”. Wokół ogniska „se obnosi božićna slama, nalažu badnjaci, peku česnica i pečenica" itp. Por. także monografię S. Trojanovicia, Vatra u običajima i životu srpskog naroda, Beograd 1930. 
Jeszcze przed zrodzeniem się podziałów społecznych i narodzeniem państw średniowiecznych, na tworzenie się słowiańskiej terminologii rodowej oddziałują czynniki gospodarcze i geograficzne. W ich wyniku, obok starych terminów nazywających wspólnoty rodowe typu *rodz, *plemę, *obitělb oraz nowszych porodica, rodbina, svojta, svojbina, blizika, zadruga i obcych typu familija, fis itp., pojawiają się również terminy pierwotnie charakteru materialnego, mieszkalnego. To bardzo istotna cecha w rozwoju semantycznym wyrazów o charakterze typowo topograficznym, prawnym, rodowym i społecznym. Już u Prasłowian terminy topograficzne, posiadając znaczenia bliskie rodowemu obliczu ich starego społeczeństwa, otrzymują nowe sensy, przy jednoczesnym zachowaniu pierwotnych znaczeń gospodarczych i geograficznych. Są to przede wszystkim wyrazy *doms 'budynek, w którym mieszka rodzina; rodzina' i *kotja 'budynek', 'rodzina', w zależności od przyjętej etymologii, pierwotnie oznaczał 'to, co pokryte, ukryte; schronienie', 'budynek, który ma kąty; kwadratowy, a nie okrągły, budynek' lub 'budynek z ogniskiem w kącie izby'. Obydwa te wyrazy cechuje specjalny paralelizm rozwoju semantycznego, szczególnie widoczny w dwóch jego najważniejszych znaczeniach: 'budynek' (potem także 'wieś, osiedle', 'ojczyzna, strony rodzime' oraz 'dwór', 'cerkiew, klasztor') i 'rodzina' (oraz 'szanowana rodzina', 'ród, część bractwa, bractwo'). Od tego równoległego rozwoju istnieją oczywiście wyjątki, nieraz bardzo ciekawe znaczenia ilustrujące rozwój semantyczny tych wyrazów, ale ogólnie rzecz biorąc, cechuje je bardzo bliska i regularna ewolucja. Wyrazy oznaczają zarówno miejsce, gdzie ktoś mieszka (być może to znaczenie pierwotne obydwu jednostek), jak i wspólnotę, najbliższych krewnych zamieszkujących dany budynek. Na przestrzeni wieków uległy one rozmaitym bardzo zbliżonym przekształceniom semantycznym, rozszerzeniom lub zawężeniom idącym czy to w kierunku bardziej abstrakcyjnym, czy konkretnym.

\section{Źródła:}

BezLAJ ESSJ, Bezlaj F., 1982, Etimološki slovar slovenskega jezika, t. II: K-O, Ljubljana: Mladinska knjiga.

BorYś SEJP, Boryś W., 2005, Stownik etymologiczny języka polskiego, Kraków: Wydawnictwo Literackie.

ВокА, Накићеновић С., 1999, Бока, Подгорица: ЦИД. 
CRmniCA, Вукмановић J., 1988, Црмница. Антропогеографска и етнолошка испитавања, Београд: Српска академија наука и уметности.

DH, Ивић П., Грковицћ М., 1976, Дечанске хрисовуље, Нови Сад: Институт за лингвистику.

ESSJA, Этимологический словарь славянских языков, 1974-, О. Н. Трубачев (red.), Москва: Наука.

GZS, Srpski građanski zakonik, w: M. Stupar (red.), Zbornik građanskih zakonika stare Jugoslavije, Titograd 1960: Grafički zavod, s. 153-267.

КВР, Ердељановић J., 1981, Кучи, Братоножићи, Пипери, Београд: Слово љубве.

KD, Новаковић C., 2004, Законик Стефана Душана, изара српског, Београд: Лирика.

KUČI, Дучић J., 1931, Живот и обичаји племена Куча, Српски етнографски зборник 48, Београд: ЦИД.

KurzBeK, 1790, Нbмецкїи и сербскій словарь на потребу сербскаго народа, Wien: Joseph Edlen Kurzbeck.

MS, Miklosich F., 2006, Monumenta serbica spectantia historiam serbiae bosnae ragusii, Viennae 1858, reprint: Beograd: Српска школска књига, Филозофски факултет.

Nuegoš, 1983, Стевановић М., Речник језика Петра Петровића Његоша, Београд-Титоград-Цетиње: САНУ, „Вук Караџић”, Народна књига, Просвета, ЦАНУ, Обод.

OIZ CG, Bogišić V., 1980, Opšti imovinski zakonik za Crnu Goru 1888, Cetinje: Obod.

PAštrović, Вукмановић J., 1960, Паштровићи. Антропогеографско-етнолошка испитавања, Цетиње.

PosrвOV, Михајловић В., 1982-1984, Посрбице од Орфелина до Вука, т. I-II, Нови Сад: Матица српска.

Rıје̌́к, Јовићевић А., 1999, Ријечка нахија у Црној Гори, Подгорица: ЦИД.

RIKSS, Даничић Ђ., 1975, Рјечник из кьижевних старина српских, т. I-III, Београд: „Вук Караџић”.

RJAZ, Rječnik hrvatskoga ili srpskoga jezika, 1880-1976, t. I-XXIII, Đ. Daničić, P. Budmani, T. Maretić (red.), Zagreb: Jugoslavenska akademija znanosti i umjetnosti.

RKAм, Јовановић В., 2004, Речник села Каменица код Ниша, Српски дијалектолошки зборник LI, Београд: Институт за српски језик САНУ, s. 313-688.

RKM, Елезовић Г., Речник косовско-метохијског дијалекта, Српски дијалектолошки зборник IV (A-Њ), Београд 1932; Српски дијалектолошки зборник VI (O-W), Београд 1934: Српска краљевска академија. 
RLESK, Митровић Б., 1984, Речник лесковачког говора, Лесковац.

RMS, Речник српскохрватскога књижевног језика, 1967-1976, т. I-VI, М. Стевановић (red.), Нови Сад: Матица српска.

RPirot, Живковић Н., 1987, Речник пиротског говора, Пирот: Музеј Понишавља.

RProš, Вујичић М., 1995, Рјечник говора Прошћења (код Мојковца), Подгорица: Црногорска академија наука и умјетности.

RRAd, Томић M., 1989, Речник радимског говора, Српски дијалектолошки зборник $X X X V$, Београд: Институт за српскохрватски језик САНУ.

RSAN, Речник српскохрватскога книжевног и народног језика, 1959-, t. 1-17, А. Белић (red.), Београд: Институт за српскохрватски језик САНУ.

RSGV, Петровић Д. (red.), 2002-2004, Речник српских говора Војводине, св. 2: В-Д, св. 4: К-љ, Нови Сад: Матица српска, Тиски цвет.

RTiмок, Динић J., 2008, Тимочки дијалекатски речник, Београд: Институт за српски језик САНУ.

RVG, Боричић Тиврански В., 2002, Речник васојевићког говора, Београд: Просвета.

RZAG, ЋупићД., ЋупићЖ., 1997,Речникговора Загарача, Српскидијалектолошки зборник XLIV, Београд: Институт за српскохрватски језик САНУ.

SEJP, Sławski F., 1952-1975, Słownik etymologiczny języka polskiego, t. I-V, Kraków: Towarzystwo Miłośników Języka Polskiego.

Sкок ER, Skok P., Etimologijski rječnik hrvatskoga ili srpskoga jezika, 1971-1974, t. I-IV, Zagreb: Jugoslavenska akademija znanosti i umjetnosti.

SNoJ SES, Snoj M., 2003, Slovenski etimološki slovar, wyd. II, Ljubljana: Modrijan založba i ZRC SAZU.

SP, Słownik prasłowiański, t. I-VIII, 1974-2001, F. Sławski, W. Boryś (red.), Wrocław-Warszawa-Kraków-Gdańsk: Zakład Narodowy im. Ossolińskich, Wydawnictwo PAN.

SR, Караџић В. С., 1935, Српски рјечник, wyd. IV, Београд: Штампарија Краљевине Југославије.

SSS, Kowalenko W., Labuda G., Lehr-Spławiński T., 1961, Słownik starożytności słowiańskich, t. I: A-E, Wrocław-Warszawa-Kraków-Gdańsk: Zakład Narodowy im. Ossolińskich, Wydawnictwo PAN.

ŠKALJIĆ A., 1973, Turcizmi u srpskohrvatskom - hrvatskosrpskom jeziku, Sarajevo: Svjetlost.

UR, Станић M., 1990-1991, Ускочки речник, т. I-II, Београд: Научна књига. 


\section{Bibliografia}

БАРЈАКТАРОВић М., 1981, О породичним задругама у Југославији данас, w: Ђ. Пејовић (red.), Предмет и метод изучавања патријархалних заједница у Југославији, Титоград: Црногорска академија наука и умјетности, s. 277-286.

Бенвенист Е., 2002, Речник индоевропских установа (привреда, сродство, друштво, власт, право, религија), Сремски Карловци-Нови Сад: Издавачка књижарница Зорана Стојановића.

BoGIšIĆ V., 1999, Zbornik pravnih običaja u Južnih Slovena - građa u odgovorima iz raznih krajeva slovenskog juga, Beograd-Podgorica: UNIREKS.

Чуьриловић В., 1959, Терминологија племенског друштва у Црној Гори, Београд: Српска академија наука, Научно дело.

Филиповић М., 1945, Несродничка и предвојена задруга, Београд.

Илић А., 1936, Систем права о кућној заједници у Црној Гори, Београд.

Илилић Н., 1999, Историја задруге код Срба, Београд: Службени лист СРЈ.

Лома А., 2004, Прасловенска лексика и култура у индоевропском контексту, w: В. Васић (red.), Предавања из историје језика, Нови Сад: Филозофски факултет, Одсек за српски језик и лингвистику, s. 15-42.

Милићевић М., 1984, Живот Срба сељака, Београд: Просвета.

НовАковић С., 2002, Народ и земља у старој српској држави, Београд: Завод за уџбенике и наставна средства.

РАкић Р., 1991, Терминологија сродства у Срба, Београд: Одељење за етнологију Филозофског факултета у Београду.

Ровински П., 1998, Етнографија Црне Горе, t. 1-2, Подгорица: ЦИД.

ВулАчић В., 1977, Трансформачија патријархалне породиче у Црној Гори, Београд: Слово љубве.

\section{Dom et kuća dans la langue et la tradition des Serbes et Monténégrins}

\section{(rés u mé)}

Cet article a comme objet la présentation du développement et de l'histoire des mots dom et kuća en langue serbe, qui se caractérisent par une évolution sémantique parallčle intéressante, perceptible avant tout dans leurs deux sens principaux. Ces mots désignaient non seulement le lieu où quelqu'un vit, un édifice habité, une maison concrète, mais aussi la communauté familiale, les proches y habitant. Ils ont 
subi à travers les sičcles des transformations, élargissements ou rétrécissements sémantiques différents, prenant un sens plus abstrait ou plus concret. Il se peut également que la spécialisation sémantique, ayant pour but la différenciation d'un élément abstrait d'un élément concret, ait été un stimulus pour créer un mot nouveau kuća à l'époque de la communauté slave. 